\title{
28 Research Square \\ Vitamin D Variants Levels Exposed and Association With the Disease Severity in Bronchial Asthma
}

Sultan S Al-Thagfan ( $\nabla$ sthqfan@taibahu.edu.sa )

Taibah University

Sameh Ahmed

Taibah University

Magdy M Emara

Taibah University

Mohamed Fawzi Awadallah

Taibah University

\section{Research}

Keywords: Bronchial Asthma, vitamin D2, vitamin D3, 25-hydroxyvitamin D3, 1,25-dihydroxyvitamin D3, immunoglobulin $\mathrm{E}$

Posted Date: June 22nd, 2020

DOI: https://doi.org/10.21203/rs.3.rs-35942/v1

License: (1) (1) This work is licensed under a Creative Commons Attribution 4.0 International License. Read Full License 


\section{Abstract}

Background: Several vitamin D variants may be involved in immunity modulation including; vitamin D2 (D2), vitamin D3 (D3), 25-hydroxyvitamin D3 (25(OH) D3) and 1,25-dihydroxyvitamin D3 (1,25-(OH)2D3). The objective of this study is to assess serum levels of vitamin $D$ variants in bronchial asthma patients and their correlations with disease activity markers.

Methods: 113 persons divided into two groups were enrolled in this study. The first group included 73 asthmatic patients (57 males and 16 females) and the second included 40 healthy adult (31 male and 9 female) as a control group. Vitamin D variants serum levels were assessed using ultra performance liquid chromatography (UPLC) with tandem mass system. Different disease activity markers were assessed and correlated with serum levels of vitamin $D$ variants. These markers included forced expiratory volume in 1 second (FEV1), forced vital capacity (FVC), FEV1/FVC\%, peak expiratory flow (PEF), forced expiratory flow25-75\% $\left(\mathrm{FEF}_{25-75 \%}\right)$, eosinophilic blood count, and total immunoglobulin $\mathrm{E}(\mathrm{IgE})$,

Results: The study showed that asthmatic patients had significant lower serum levels of vitamin $D$ variants in comparison with the healthy control group ( $p \leq 0.001)$. Also, serum vitamin $D$ variants levels were significantly decreased in uncontrolled asthmatic patients as compared with the partially controlled and controlled patients. The correlation values were higher for 25(OH) D3 and 1,25-(OH) 2D3 compared to D2 and D3. Negative correlations were seen for eosinophilic blood count, total IgE and ACT.

Conclusion: Serum levels of all vitamin D variants were reduced in asthmatic patients with moderate to strong correlations to the disease severity. These results suggest that vitamin D deficiency or even insufficiency may play a role in disease severity.

\section{Background}

Asthma has been recognized as one of the most prevalent chronic diseases, and its incidence has risen globally in recent decades (1). The innate and adaptive immune systems take a major part in asthma pathogenesis. The innate and adaptive immune systems are complex in nature with many redundant and disruptive pathways that may play a significant role in asthma pathogenesis (2). The vitamin $D$ has recently emerged as an important pathway to innate and adaptive immune systems that could be important to primary asthma treatment, asthma reduction or protection and asthma exacerbation modulation (3). Insufficiency of vitamin D is increasingly recognized and largely referred to dietary, lifestyle and behavioral changes in general population (4).

Vitamin D have two main forms; vitamin D2 (ergocalciferol, D2) that is from plant origin and not synthesized in human and vitamin D3 (cholecalciferol, D3) that is produced from skin exposure to sunlight and obtained from animal sources as well (5). D2 have been considered as effective as D3 for bone health. However, it was advocated that D3 is about three times more powerful to preserve serum levels (6). This is attributed to the higher binding affinity of D3 to protein compared to D2. This helps D3 to live longer in the bloodstream and to increase the production quickly to adequate levels (7). Both D2 
and D3 are hydroxylated at position 25 in liver through vitamin D-25-hydroxylase (CYP2R1) to generate the most important circulating vitamin $D$ metabolite of $25(\mathrm{OH}) \mathrm{D}$ that is used to assess a patient's vitamin D status (8). In the kidneys, the 25(OH) D-1a-hydroxylase (CYP27B1) offers further hydroxylation for $25(\mathrm{OH}) \mathrm{D}$ to produce the secosteroid hormone $1 \mathrm{a}, 25$-dihydroxyvitame $\mathrm{D}(1,25[\mathrm{OH}] 2 \mathrm{D}$ where it is bound to a vitamin D-binding protein called a-globulin protein (9). Vitamin D is either absorbed by skin or swallowed then absorbed through the intestines to be carried over to the liver via the bloodstream where hydroxylation processes are initiated then bound up to the binding protein (albumin or vitamin $D$ binding protein) (10). It is converted in the liver into $25(\mathrm{OH})$ vitamin $D$ (calcidiol) that is vitamin D's main circulating form and the most widely assessed serum circulatory vitamin D. It is then transformed into 1,25 dihydroxy-vitamin $\mathrm{D}$ (calcitriol) in the kidneys, the biologically active vitamin D. Vitamin D2 metabolites appear to bind less strongly to the vitamin D-binding protein (8).

Vitamin $D$ tends to have regulatory impacts on the immune system, as a number of immune-based disorders are related with vitamin $D$ deficiencies. The activity of vitamin $D$ may be directly on the airway, since vitamin $D$ stimulates steroid sensitivity and can regulate the inflammatory condition through cytokine output and gene expression (11). Vitamin D receptors are found in the airways and are believed to suppress $C D 4+T$ cell, interleukin-2, interferon gamma, macrophages and proinflammatory cytokines (12). Vitamin D deficiency may be linked with the failure to turn off the inflammatory process, after acute inhalation provocation, with modulation of leukotrienes, prostaglandin, macrophages, and $\mathrm{T}$ cell activation and recruitment (13).

Now, the question is which mechanism used by various variants of vitamin $D$ to exert their biological effects on inflammation, remodeling, hyper-responsiveness of airways and thus asthma control. The solution to this problem would inevitably be complex, considering the larger impact of vitamin $D$ on epithelium airway, smooth muscle of bronchi, and immune cells essential to asthma pathogenesis (14). Although the optimum level of serum vitamin D, i.e., $25(\mathrm{OH}) \mathrm{D}$, for general health is at least $30-40 \mathrm{ng} / \mathrm{mL}$, there is no agreement regarding the desirable levels of different vitamin $D$ variants and there impacts on severity of the disease (14).

Therefore, this work was conducted to assess vitamin $D$ variants serum levels in bronchial asthma patients including; D2, D3, 25(OH) D3 and 1,25-(OH) 2D3 and to investigate their correlations with disease activity markers. The study also shed light on the role exerted by different vitamin $\mathrm{D}$ variants on pathogenesis of bronchial asthma.

\section{Methods}

113 persons were enrolled in this cross-sectional case-control study divided into two groups. First group included 73 adult asthmatic patients (57 males and 16 females) who were examined by Chest Diseases Department at Taibah University Clinics between April 2018 and September 2019. In compliance with the Guidelines for the Global Asthma Initiative (GINA)(15), In particular, asthma control levels were classified according to daytime symptoms, activities limitations, and nocturnal wake-up symptoms, need for relief 
care and FEV1 results. .Asthma was classified by level of control as controlled (32 patients, 43.83\%), partially controlled (24 patients, 32.88\%) or uncontrolled (17 patients, $23.29 \%$ ). Asthma has been diagnosed by history of paroxysmal attacks of wheezy chest, dyspnea, cough and expectoration or documented reversible airway obstruction as determined by a $12 \%$ improvement in FEV1 or an increase of FEV1 by $200 \mathrm{cc}$ after bronchodilator inhalation of $400 \mu \mathrm{g}$ salbutamol or Peak expiratory flow rate variability (>20\%). Pregnant women, smokers, patients with co-morbid illness other than bronchial asthma who may have an effect on serum vitamin D levels have been excluded. Also, patients on nutritional therapy with possible impacts on serum $25(\mathrm{OH}) \mathrm{D}$ levels were omitted. All patients have been followed up at Taibah University Clinics, Saudia Arabia. All subjects were subjected to complete medical history, general and local chest examinations, plain P-A chest X-ray, routine laboratory examinations and spirometry. Spirolab III - MIR Medical International Research Computerized Spirometry was used for spirometry examination (FVC, FEV1, FEV1/FVC\%, $\mathrm{PEF} \mathrm{FEF}_{25-75 \%}$ ). At least three spirometry maneuvers were conducted by each subject and the highest values were selected. The procedure was performed 20 min after inhalation of 4 salbutamol puffs, each comprising $100 \mu \mathrm{g}$ of salbutamol.

\section{Measurements serum levels of vitamin D variants}

Two milliliters of venous blood was obtained, centrifuged and serum was separated then stored at $20^{\circ} \mathrm{C}$ until time of assay. Serum levels of vitamin D variants including D2, D3, 25(OH) D3 and 1,25-(OH)2D3 were quantified using ultra performance liquid chromatography (UPLC) system with tandem mass detector system. The system was made up of Waters Quattro Premier XE tandem mass spectrometer (Waters Corporation, USA). The detection limits are $10 \mathrm{pg} \mathrm{mL}^{-1}$ for D3, $12 \mathrm{pg} \mathrm{mL}^{-1}$ for D2, $11 \mathrm{pg} \mathrm{mL}^{-1}$ for $25(\mathrm{OH}) \mathrm{D} 3$ and $10 \mathrm{pg} \mathrm{mL}^{-1}$ for $1,25(\mathrm{OH}) 2 \mathrm{D} 3$. Data have been presented as the mean \pm standard error of the mean (SEM).

\section{Statistical analysis}

The 20th version of the Statistical Package for the Social Sciences (SPSS) (International Business Machines Corp., Armonk, New York, USA) was used for statistical analysis. Data is statistically evaluated using the Chi Square Analysis, Students' unpaired t-test and analysis of variance (ANOVA). Significance was assessed by $p$-value where the results considered non-significant $(P>0.05)$, significant $(P<0.05)$ and highly significant $(P<0.001)$. The correlation strength was strictly defined, following Evan's method $(16)$, where the association was perceived to be very strong, strong, moderate, weak or very weak when $(0.8 \leq r$ $\leq 1.0),(0.6 \leq r<0.8),(0.4 \leq r<0.6),(0.2 \leq r<0.4)$ or $(0.0 \leq r<0.2)$, respectively

\section{Results}

One hundred thirteen subjects (73 asthmatic patients and 40 healthy volunteers as a control group) were investigated through a cross-sectional case-control study between April 2018 and September 2019 in AlMadinah Al-Munwarrah, Saudi Arabia.. Demographic data of the patients were; the mean patient age was $44.7 \pm 12.2$ years, and the average asthma duration for the patients was $5.20 \pm 5.6$ years (Table 1 ). There was no significance differences between asthmatic patients and healthy subjects in demographic data 
related to age, height and body mass index. However, there was a difference in body weight. The clinical features of asthmatic patients and control groups were compared (Table (2)). The Asthma Control Test (ACT) offers a standardized score to help you and your healthcare professional to assess whether symptoms of asthma are well managed. The average ACT results for asthmatic patient group were 17.4 \pm 3 .3. There were highly significant differences between studied groups as regard FEV $1 \%, F V C \%$ and PEF\% that were lower in asthmatic patients compared to healthy group $(P \leq 0.001)$. Asthmatic patients had higher serum total IgE level and higher number of eosinophil cells.

Table 1

Comparison of demographic data between asthmatic patients and control groups.

\begin{tabular}{|llll|}
\hline Features of the participant & $\begin{array}{l}\text { patients group } \\
(\mathbf{n = 7 3 )}\end{array}$ & $\begin{array}{l}\text { Control group } \\
(\mathbf{n}=\mathbf{4 0})\end{array}$ & $P$ Value \\
\hline Demographic features & $44.2 \pm 13.6$ & $43.2 \pm 11.4$ & $\mathrm{NS}$ \\
Age (years) & $57(78.1 \%)$ & $31(77.5 \%)$ & $\mathrm{NS}$ \\
Male & $16(21.9 \%)$ & $9(22.5 \%)$ & $\mathrm{NS}$ \\
Female & $84.8 \pm 19.9$ & $71.8 \pm 15.6$ & $\leq 0.01(\mathrm{~S})$ \\
Weight $(\mathrm{Kg})$ & $165.8 \pm 11.1$ & $166.2 \pm 9.8$ & $\mathrm{NS}$ \\
Height $(\mathrm{cm})$ & & & \\
\hline Body mass index (kg/m $\left.{ }^{2}\right)$ & $30.6 \pm 6.3$ & $29.4 \pm 3.4$ & $\mathrm{NS}$ \\
Duration of disease (years) & $5.20 \pm 5.6$ & - & - \\
\hline a Mean \pm SEM & & & \\
\hline BMl, body mass index; NS, non-significant; SEM, standard error of the mean. \\
\hline
\end{tabular}


Table 2

Comparison of clinical features between asthmatic patients and control groups.

\begin{tabular}{|c|c|c|c|}
\hline Parameter & $\begin{array}{l}\text { patients group } \\
(n=73)\end{array}$ & $\begin{array}{l}\text { Control group } \\
(n=40)\end{array}$ & $P$ Value \\
\hline ACT & $17.4 \pm 3.3$ & - & - \\
\hline FEV1\% & $79.0 \pm 18.9$ & $95 \pm 2.1$ & $\leq 0.001(\mathrm{HS})$ \\
\hline FVC\% & $73.9 \pm 16.6$ & $92 \pm 1.8$ & $\leq 0.001(\mathrm{HS})$ \\
\hline FEV1/FVC\% & $109 \pm 15.8$ & $103 \pm 2.2$ & $\leq 0.01(\mathrm{~S})$ \\
\hline PEF\% & $75.8 \pm 19.9$ & $95 \pm 2.1$ & $\leq 0.001(\mathrm{HS})$ \\
\hline $\mathrm{FEF}_{25-75 \%}$ & $94.2 \pm 33.3$ & $92 \pm 3.9$ & $\leq 0.01(\mathrm{~S})$ \\
\hline Total lgE (IU/mL) & $304.1 \pm 68.5$ & $47 \pm 6.9$ & $\leq 0.001(\mathrm{HS})$ \\
\hline Eosinophilic count (Cell/ $\mu \mathrm{L})$ & $444.1 \pm 97.5$ & $147 \pm 82.5$ & $\leq 0.001(\mathrm{HS})$ \\
\hline \multicolumn{4}{|l|}{ * Mean \pm SEM, } \\
\hline $\begin{array}{l}\text { ACT, Asthma Control Test; FE } \\
\text { Volume in } 1 \text { second; FVC, For } \\
\text { Peak Expiratory Flow; S, signi }\end{array}$ & $\begin{array}{l}\text { Forced Expiratory } \\
\text { Capacity; HS, hig }\end{array}$ & $\begin{array}{l}\text { 25-75\%; FEV1, Fc } \\
\text { gnificant; IgE, Imn }\end{array}$ & $\begin{array}{l}\text { Expiratory } \\
\text { lobulin E; PEF, }\end{array}$ \\
\hline
\end{tabular}

With regards to serum levels of vitamin $D$ variants in asthmatic patients, serum levels of $D_{3}, D_{2}, 25(\mathrm{OH})$ $D_{3}$ and $1,25(\mathrm{OH})_{2} D_{3}$ were significantly higher compared to healthy group with $P$ values $\leq 0.001$. Results of serum levels of vitamin $D$ variants in asthmatic patients and healthy groups were presented in Table (3). Furthermore, asthmatic patients were classified according to asthma control to three subgroups: controlled, partially controlled and uncontrolled patients. It was seen that serum levels of $D_{3}$, $\mathrm{D}_{2}, 25(\mathrm{OH}) \mathrm{D}_{3}$ and $1,25(\mathrm{OH})_{2} \mathrm{D}_{3}$ were lower in uncontrolled group compared to partially controlled and controlled patient groups (Fig. 1). Associations of clinical, and laboratory features of asthmatic patients and vitamin D variants levels were described using Evan's method(16). A week negative correlation was seen between ACT and D2 while moderate negative correlation with $D_{3}$ and strong negative correlations with $25(\mathrm{OH}) \mathrm{D}_{3}$ and $1,25(\mathrm{OH})_{2} \mathrm{D}_{3}$. For FEV1\%, FVC\% and FEV1/FVC moderate positive correlation with $\mathrm{D}_{2}$ and strong positive correlations with $\mathrm{D}_{3}, 25(\mathrm{OH}) \mathrm{D}_{3}$ and $1,25(\mathrm{OH})_{2} \mathrm{D}_{3}$. While for PEF\% week positive correlation was noticed for $D_{2}$, moderate positive correlations for $D_{3}$, and $1,25(\mathrm{OH})_{2} \mathrm{D}_{3}$ and strong positive correlation with $25(\mathrm{OH}) \mathrm{D}_{3}$. On the other hand, week positive correlations were noticed for $\mathrm{FEF}_{25-75}$ with $1,25(\mathrm{OH})_{2} \mathrm{D}_{3}$ and moderate positive correlations for $\mathrm{D}_{2}, \mathrm{D}_{3}$ and $25(\mathrm{OH}) \mathrm{D}_{3}$ with $\mathrm{FEF}_{25-75}$. Concerning IGE and eosinophil cells, strong negative correlations were found with $\mathrm{D}_{3}, 25(\mathrm{OH}) \mathrm{D}_{3}$ and $1,25(\mathrm{OH})_{2} \mathrm{D}_{3}$ whereas moderate negative correlation with $D_{2}$. Data distribution of vitamin $D$ variants against $F E V 1 \%$ is shown in Fig. 2. 


\section{Discussions}

A vitamin $D$ deficiency is related to a number of immunologically induced diseases such as asthma with its regulatory effects on the immune system (17). The existence of associations of vitamin D with asthma remains unclear. The current study shed lights on roles of different vitamin $D$ variants on severity of bronchial asthma. The involved subjects were divided into asthmatic patients and healthy groups with no significance differences in demographic data except body weight. The clinical features of between asthmatic patients and control groups revealed significant differences with $p$ value $<0.01$. The present study measures for the first time serum levels of vitamin $D$ variants in asthmatic patients including; $D_{3}$, $\mathrm{D}_{2}, 25(\mathrm{OH}) \mathrm{D}_{3}$ and $1,25(\mathrm{OH})_{2} \mathrm{D}_{3}$ (Table 3). It was clear that high significant difference between asthmatic and healthy groups for all vitamin $D$ variants serum levels with $P$ values $\leq 0.001$. These findings agree with previous reports concerning vitamin $D$ deficiency correlations in bronchial asthma patients (18-20). However, most of these reports used $25(\mathrm{OH}) \mathrm{D}_{3}$ as a marker for the overall vitamin $D$ levels. The roles of other vitamin $D$ variants could not be ignored. A variety of influencing variables can affect such relationships; one is that subjects with asthma expend more time indoors so that they will be subjected to less sunlight (21). Additionally, asthmatic patients were classified according to asthma control to three subgroups: controlled, partially controlled and uncontrolled patients. It was seen that serum levels of $D_{3}$, $\mathrm{D}_{2}, 25(\mathrm{OH}) \mathrm{D}_{3}$ and $1,25(\mathrm{OH})_{2} \mathrm{D}_{3}$ were lower in uncontrolled group compared to partially controlled and controlled patient groups (Fig. 1). The level of vitamin D insufficiency was greatest in patients with uncontrolled asthma: the results of this study confirm and expand in adult patients with varying degrees of asthma control in previous reports that vitamin D status is correlated with asthma severity (22).

Table 3

Serum levels of vitamin D variants in asthmatic patients and control groups.

\begin{tabular}{|llll|}
\hline Vitamin D variants & $\begin{array}{l}\text { Patients group } \\
(\mathbf{n = 7 3})\end{array}$ & $\begin{array}{l}\text { Control group } \\
(\mathbf{n}=\mathbf{4 0})\end{array}$ & PValue \\
\hline $\mathrm{D}_{2}(\mathrm{ng} / \mathrm{mL})$ & $21.0 \pm 5.13$ & $26.2 \pm 52.7$ & $\leq 0.001(\mathrm{HS})$ \\
\hline $\mathrm{D}_{3}(\mathrm{ng} / \mathrm{mL})$ & $19.6 \pm 5.65$ & $23.0 \pm 6.61$ & $\leq 0.001(\mathrm{HS})$ \\
\hline $25-(\mathrm{OH}) \mathrm{D}_{3}(\mathrm{ng} / \mathrm{mL})$ & $14.7 \pm 3.46$ & $18.4 \pm 4.32$ & $\leq 0.001(\mathrm{HS})$ \\
\hline $1,25-(\mathrm{OH}) 2-\mathrm{D}_{3}(\mathrm{pg} / \mathrm{mL})$ & $45.6 \pm 8.85$ & $72.3 \pm 12.7$ & $\leq 0.001(\mathrm{HS})$ \\
\hline a Mean \pm SEM & & & \\
\hline HS, highly significant; S, significant; SEM, standard error of the mean. & \\
\hline
\end{tabular}


Table 4

Correlation of clinical, and laboratory features of asthmatic patients and vitamin D variants levels.

\begin{tabular}{|c|c|c|c|c|}
\hline Features & $\begin{array}{l}D-2 \\
(r)\end{array}$ & $\begin{array}{l}D-3 \\
(r)\end{array}$ & $\begin{array}{l}25-(\mathrm{OH}) D_{3} \\
(r)\end{array}$ & $\begin{array}{l}1,25-(\mathrm{OH}) 2-\mathrm{D}_{3} \\
(\mathrm{r})\end{array}$ \\
\hline ACT & -0.39 & -0.49 & -0.62 & -0.67 \\
\hline FEV1\% & 0.56 & 0.62 & 0.73 & 0.64 \\
\hline FVC\% & 0.49 & 0.65 & 0.76 & 0.65 \\
\hline FEV1/FVC\% & 0.48 & 0.62 & 0.74 & 0.64 \\
\hline PEF\% & 0.36 & 0.51 & 0.61 & 0.48 \\
\hline $\mathrm{FEF}_{25-75 \%}$ & 0.40 & 0.59 & 0.52 & 0.36 \\
\hline Total IgE & -0.51 & -0.69 & -0.75 & -0.70 \\
\hline Eosinophilic count & -0.53 & -0.69 & -0.72 & -0.68 \\
\hline
\end{tabular}

Asthma pathogenesis could be implied by several mechanisms by vitamin $D$ deficiency. Vitamin $D$ receptors found in the airways are believed to suppress proinflammatory cytokines with impacts on interleukin-2, interferon-gamma, CD4 + T cells, and macrophages. Vitamin D deficiency can be linked with an inability to turn off the inflammatory process, after acute inhalation provocation, with modulation of prostaglandin, leukotrienes, macrophages, and T cell activation and recruitment (23). Vitamin D is potentially able to regulate the poor reaction of glucocorticoids in severe asthma by increasing interleukin-10 (a strong anti-inflammatory cytokine) production in CD4 + T cells (24). In other words, vitamin $D$ restores the ability of regulatory $T$ cells to secrete interleukin-10 in response to steroids from steroid-resistant patients with bronchial asthma.

In this study, strong negative correlations were observed between ACT with 25(OH) $D_{3}$ and 1,25(OH)2D3 while a moderate negative correlation with $\mathrm{D} 3$ and a week negative correlation for $\mathrm{D} 2$. These results pointed for the predominate role of $25(\mathrm{OH}) \mathrm{D}_{3}$ and 1,25(OH)2D3 deficiency in asthma pathogenesis. Vitamin D2 metabolites appear to bind less strongly to the vitamin D-binding protein (8). On the other hand, FEV1\%, FVC\% and FEV1/FVC showed strong positive correlations with $\mathrm{D}_{3}, 25(\mathrm{OH}) \mathrm{D}_{3}$ and $1,25(\mathrm{OH}) 2 \mathrm{D} 3$ whereas moderate positive correlation with $\mathrm{D}_{2}$. This finding agrees with Black and Scragg who reported similar association with FEV1\% (25). This could be explained by that vitamin D3 variants inhibit the formation of metalloproteinase matrix and proliferation of fibroblasts and affects synthesis of collagen; this means that 1,25(OH)2D3 can influence tissue remodeling and possibly lung function (26). Additionally, as strong positive correlation was found between PEF\% and 25(OH)D3 whereas moderate 
positive correlations for PEF\% with $D_{3}, 1,25(\mathrm{OH}) 2 \mathrm{D} 3$ and week positive correlation with $\mathrm{D}_{2}$. On the other hand, week positive correlations were noticed for FEF25-75 with 1,25(OH)2D3 and moderate positive correlations for D2, D3 and 25(OH) D3 with FEF25-75. These results coincide with previous reports concerning association of 25(OH) D3 with pulmonary functions (27). However, this study was the first to report associations of vitamin $D$ variants with spirometry results. Concerning eosinophil cells, strong negative correlations were found with $\mathrm{D} 3,25(\mathrm{OH}) \mathrm{D} 3$ and 1,25(OH)2D3 whereas moderate negative correlation with D2. This can be explained by the association of eosinophil with T-Helper type 2 (Th2) effector arm with cell immunity in an allergic response (28). However, the correlations between circulating eosinophils serum levels of vitamin D variants were firstly reported in this study. Concerning total IGE, strong negative correlations were found with $\mathrm{D} 3,25(\mathrm{OH}) \mathrm{D} 3$ and 1,25(OH)2D3 whereas moderate negative correlation with $D 2$. Vitamin $D$ is regulator for lgE circulating level. Vitamin $D$ directly affects the B-cells to induce B10 cells and B-cells induce IL-10 production that limit the secretion of IgE. Moreover, vitamin $D$ has indirect effects on other types of cells that maintain the lgE response. The possible benefits of vitamin $D$ include modulation of the host's IgE reaction by direct and indirect regulation (29).

The restriction of the current cross-sectional study is the limited number of asthmatic patients in a single hospital center. However, the power of the study was sufficient to show real differences and it was the first time to comparatively weigh the role of each vitamin $D$ variant in asthma severity. The patients require a longitudinal follow-up since assessment for life quality and its relationship with vitamin $D$ deficiency may help to improved health care and longer-term outputs.

\section{Conclusion}

In conclusion, serum levels of vitamin D variant were diminished significantly in asthmatic patients. The serum levels of vitamin $\mathrm{D}$ variants were moderately to strongly correlate to the asthma severity. The predominate role of serum levels of 25(OH) D3 and 1,25(OH)2D3 in disease pathogenesis was clear. These results imply that vitamin $D$ deficiency or insufficiency may affect disease severity. However, these results require further multicenter, larger scale clinical investigations.

\section{Declarations}

\section{Ethics approval and consent to participate}

Ethical Committee of Taibah University, Saudia Arabia approved the study protocol (Approval No. TUCDREC/20171204). An informed consent was received from patients.

\section{Consent for publication}

Not applicable

\section{Availability of data and materials}


The datasets used and/or analysed during the current study are available from the corresponding author on reasonable request

\section{Competing interests}

Authors declare that there is no conflict of interest

\section{Funding}

Deanship of Scientific Research at Taibah University, Saudi Arabia, for the financial support (Fund No. 8042/1438)

\section{Authors' contributions}

1. S. Al-Thagfan had full access to all of the data in the study and take responsibility for the integrity of the data and the accuracy of the data analysis, including and especially any adverse effects. M. M. Emara had full access to all of the data in the study and contributed substantially to the study design, data analysis and interpretation, and the writing of the manuscript. S. Ahmed and M. F. Awadallah contributed substantially to the study design, data analysis and interpretation, and the writing of the manuscript. All authors read and approved the final manuscript.

\section{Acknowledgements}

Authors express appreciation for Toxicological Research \& Studies Center and the Deanship of Scientific Research at Taibah University, Saudi Arabia, for the financial support and offering the required facilities for this project.

\section{References}

1. 1. Bateman ED, Hurd SS, Barnes PJ, Bousquet J, Drazen JM, FitzGerald JM, et al. Global strategy for asthma management and prevention: GINA executive summary. The European respiratory journal. 2008;31(1):143 - 78.

2. 2. Eisenbarth SC, Cassel S, Bottomly K. Understanding asthma pathogenesis: linking innate and adaptive immunity. Current opinion in pediatrics. 2004;16(6):659- 66.

3. 3. Litonjua AA, Weiss ST. Is vitamin D deficiency to blame for the asthma epidemic? The Journal of allergy and clinical immunology. 2007;120(5):1031-5.

4. 4. Ginde AA, Mansbach JM, Camargo CA, Jr. Association between serum 25-hydroxyvitamin D level and upper respiratory tract infection in the Third National Health and Nutrition Examination Survey. Archives of internal medicine. 2009;169(4):384 - 90.

5. 5. Borji S, Rafieian-Kopaei M. Vitamin D and its importance on public health. J parathyr dis. 2016;4(1):20 - 4. 
6. 6. Armas LA, Hollis BW, Heaney RP. Vitamin D2 is much less effective than vitamin D3 in humans. The Journal of clinical endocrinology and metabolism. 2004;89(11):5387-91.

7. 7. Chun RF, Hernandez I, Pereira R, Swinkles L, Huijs T, Zhou R, et al. Differential Responses to Vitamin D2 and Vitamin D3 Are Associated With Variations in Free 25-Hydroxyvitamin D. Endocrinology. 2016;157(9):3420-30.

8. 8. Bikle DD. Vitamin D metabolism, mechanism of action, and clinical applications. Chem Biol. 2014;21(3):319 - 29.

9. 9. Christakos S, Ajibade DV, Dhawan P, Fechner AJ, Mady LJ. Vitamin D: metabolism. Endocrinol Metab Clin North Am. 2010;39(2):243 - 53.

10. 10. Hossein-nezhad A, Holick MF. Vitamin D for health: a global perspective. Mayo Clinic proceedings. 2013;88(7):720 - 55.

11. 11. Medrano M, Carrillo-Cruz E, Montero I, Perez-Simon JA. Vitamin D: Effect on Haematopoiesis and Immune System and Clinical Applications. Int J Mol Sci. 2018;19(9):2663.

12. 12. Yin K, Agrawal DK. Vitamin D and inflammatory diseases. J Inflamm Res. 2014;7:69-87.

13. 13. Mangin $M$, Sinha R, Fincher K. Inflammation and vitamin D: the infection connection. Inflamm Res. 2014;63(10):803 - 19.

14. 14. Hall SC, Agrawal DK. Vitamin D and Bronchial Asthma: An Overview of Data From the Past 5 Years. Clin Ther. 2017;39(5):917 - 29.

15. 15. Boulet L-P, Reddel HK, Bateman E, Pedersen S, FitzGerald JM, O'Byrne PM. The Global Initiative for Asthma (GINA): 25 years later. European Respiratory Journal. 2019;54(2):1900598.

16. 16. Evans JD. Straightforward statistics for the behavioral sciences. Pacific Grove, CA: Brooks/Cole Publishing Co.; 1996.

17. 17. Eman Shebl R, Shehata SM, Elgabry M, Ali SAl, Elsaid HH. Vitamin D and phenotypes of bronchial asthma. Egyptian Journal of Chest Diseases and Tuberculosis. 2013;62(2):201-5.

18. 18. Korn $S$, Hübner $M$, Jung $M$, Blettner $M$, Buhl R. Severe and uncontrolled adult asthma is associated with vitamin D insufficiency and deficiency. Respir Res. 2013;14(1):25-.

19. 19. Brehm JM, Schuemann B, Fuhlbrigge AL, Hollis BW, Strunk RC, Zeiger RS, et al. Serum vitamin D levels and severe asthma exacerbations in the Childhood Asthma Management Program study. The Journal of allergy and clinical immunology. 2010;126(1):52 - 8.e5.

20. 20. Niruban SJ, Alagiakrishnan K, Beach J, Senthilselvan A. Association between vitamin D and respiratory outcomes in Canadian adolescents and adults. The Journal of asthma : official journal of the Association for the Care of Asthma. 2015;52(7):653 - 61.

21. 21. Shahin MYA, El-lawah AA, Amin A, El-Tawil IAH. Study of serum vitamin D level in adult patients with bronchial asthma. Egyptian Journal of Chest Diseases and Tuberculosis. 2017;66(1):5-9.

22. 22. Gupta A, Sjoukes A, Richards D, Banya W, Hawrylowicz C, Bush A, et al. Relationship between serum vitamin $D$, disease severity, and airway remodeling in children with asthma. Am J Respir Crit Care Med. 2011;184(12):1342-9. 
23. 23. Somashekar AR, Prithvi AB, Gowda MNV. Vitamin d levels in children with bronchial asthma. J Clin Diagn Res. 2014;8(10):PC04-PC7.

24. 24. Xystrakis E, Kusumakar S, Boswell S, Peek E, Urry Z, Richards DF, et al. Reversing the defective induction of IL-10-secreting regulatory $T$ cells in glucocorticoid-resistant asthma patients. J Clin Invest. 2006;116(1):146 - 55.

25. 25. Black PN, Scragg R. Relationship between serum 25 -hydroxyvitamin $d$ and pulmonary function in the third national health and nutrition examination survey. Chest. 2005;128(6):3792-8.

26. 26. Mozos I, Marginean O. Links between Vitamin D Deficiency and Cardiovascular Diseases. Biomed Res Int. 2015;2015:109275-.

27. 27. Moghaddassi M, Pazoki M, Salimzadeh A, Ramim T, Alipour Z. Association of Serum Level of 25Hydroxy Vitamin D Deficiency and Pulmonary Function in Healthy Individuals. ScientificWorldJournal. 2018;2018:3860921-.

28. 28. Souto Filho JTD, de Andrade AS, Ribeiro FM, Alves PdAS, Simonini VRF. Impact of vitamin D deficiency on increased blood eosinophil counts. Hematology/Oncology and Stem Cell Therapy. 2018;11(1):25 - 9 .

29. 29. James J, Weaver V, Cantorna MT. Control of Circulating IgE by the Vitamin D Receptor In Vivo Involves B Cell Intrinsic and Extrinsic Mechanisms. Journal of immunology (Baltimore, Md : 1950). 2017;198(3):1164-71.

\section{Figures}

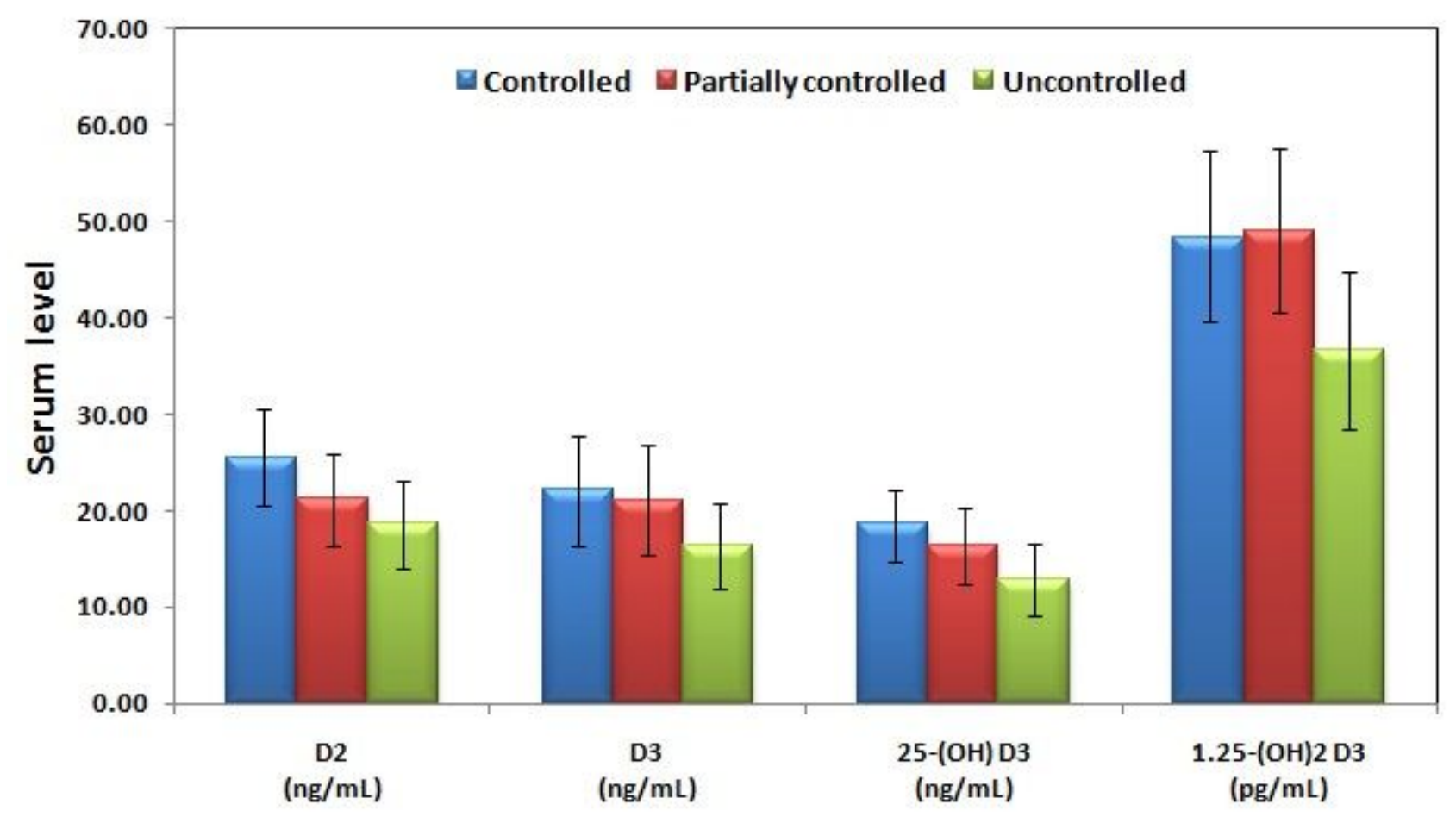

Figure 1 
Serum levels of D3, D2, 25(OH) D3 and 1,25(OH)2D3 in uncontrolled, partially controlled and controlled patient groups.
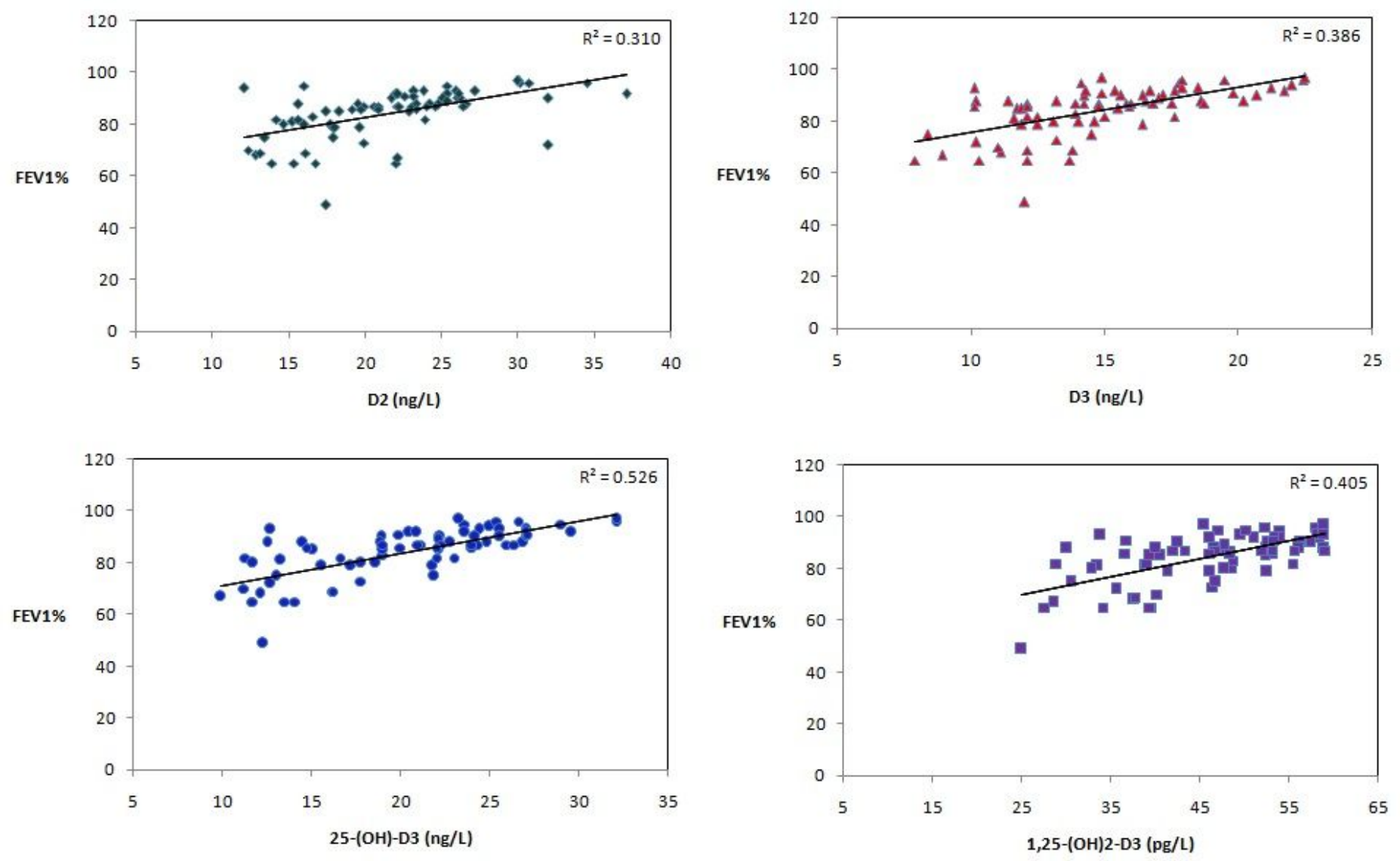

Figure 2

Data distribution of vitamin D variants against FEV1\%. 